\title{
Understanding Veterans Through the Lens of Dialogical Psychology and Theology
}

\author{
Jan Grimell ${ }^{10}$ \\ Vrije Universiteit Amsterdam
}

\begin{abstract}
A dialogical self theory framework has shown to be a promising methodology in the pursuit of mapping and gridding the psychological topography among military personnel during transition from military to civilian life and thereby advance the understandings of self-identity work in the process. This article demonstrates this methodology through a case study example drawn from a longitudinal research project that followed nineteen Swedish service members with annual interviews over a three-year period as they transitioned to civilian life. This case study example evolves into a discussion about a potential vulnerability that may be inherit among service members with distinct religious/spiritual/ethical positions in the self when or if those I-positions perceive themselves to be violated as a result of military service. The implication of such violations or transgressions may result in a type of spiritual injury that disconnects the spiritual capacity of the self to varying degrees. It is proposed that such spiritual injury is typically followed by monologue instead of dialogue. Theological concepts of forgiveness and acceptance may gradually restore the dialogical capacity between a violated position(s) and a traumatized military position within the self. Acceptance and dialogical evolution may then begin to heal the spiritual damage.
\end{abstract}

Keywords:

Dialogical self, military to civilian life, self-identity work, spiritual injury

Diyalojik Psikoloji ve İlahiyat Bakış Açılarından Gazileri Anlamak

$\mathrm{O} z$

Diyalojik benlik kuramı çerçevesi, ordudan sivil hayata geçiş sürecinde askeri personelin psikolojik topoğrafyasını "haritalama" ve derinlemesine inceleme ve böylece bu süreç içerisinde öz kimlik süreçlerini daha iyi anlama arayıșı açısından umut verici bir metodoloji olarak görülmüsștür. Bu makale, bu metodolojiyi, ylllık görüşmelerle on dokuz İsveçli askerin sivil hayata geçişlerindeki üç ylllık süre boyunca takip eden boylamsal bir araştırma projesinden alınan bir durum çalışması ile sunmaktadır. Bu durum çalışması, benlikleri içinde belirgin dini/manevi/ahlaki konumlara sahip askerlerde, bu ben-konumları (I-position), askerlik hizmetinin bir sonucu olarak ihlal edildiğinde ortaya çıkan potansiyel zedelenebilirlik hakkındaki bir tartışmaya dönüşmektedir. Bu ihlal veya haddini aşmalar, benliğin ruhsal kapasitesini değișen derecelerde koparan bir tür manevi incinme ile sonuçlanabilmektedir. Bu tür bir manevi incinmenin tipik olarak diyalog yerine monolog tarafından izlendiği düşünülmektedir. Teolojik kavramlar olarak affetme ve kabul etme, ihlal edilen pozisyon(lar) ile zedelenmiş askeri pozisyon arasındaki diyalojik kapasiteyi kademeli olarak onarabilir. Kabul ve diyalojik tekamül böylece manevi hasarı iyileștirmeye başlayabilir.

Anahtar Kelimeler:

Diyalojik benlik, askeri hayattan sivil hayata geçiş, benlik-kimlik çalışması, manevi incinme

1 Correspondence to: Jan Grimell, The Amsterdam Center for the Study of Lived Religion, Vrije Universiteit. Email: j.m.grimell@vu.nl

Citation: Grimell, J. (2018). Understanding veterans through the lens of dialogical psychology and theology. Spiritual Psychology and Counseling, 3, 139-160. http://dx.doi.org/10.12738/spc.2018.3.2.0035 
Military identities are shaped among individuals by values, meanings, and practices inherit in military cultures. Research suggests that such learned military identities often grow strong in service members' selves (Adler, Zamorski \& Britt, 2011; Bélanger \& Moore, 2013; Brunger, Serrato \& Ogden, 2013; Haynie \& Shepherd, 2011; Rosenberg, 1993; Thornborrow \& Brown, 2009). This implication of military service suggests that transition from military to civilian life involves narrative identity reconstruction as alternate stories of who I am are about to form in the pursuit of a civilian life and reintegration into civilian population (Bragin, 2010; Buell, 2010; Drops, 1979; Grimell, 2015; Savion, 2009; Yanos, 2004. This process may become taxing and accentuate or accelerate existential, moral, and/or religious dimensions in the aftermath of military service that not only can affect the service members, but also influence their partners, families, religious and/or other communities, and even health care systems (Bryan, Graham \& Roberge, 2015; Grimell, 2016b; Kopacz \& Connery, 2015; Litz et al., 2009). Self-identity work in transition to civilian life may place emphasis upon the individual and his or her personal processes during the journey to a civilian life. A dialogical approach to identity reformulation may serve as a contrast to a more individual-tailored understanding of such processes (Hermans $\&$ Hermans-Konopka, 2010). From this outlook, self-identity work in transition from military to civilian life rather emphasizes the dialogical process between I-positions of the self (e.g., 'I as a soldier', 'I as a husband', 'I as a father', 'I as a believer', and 'I as a member of a congregation') and significant others or promoters who can support the process. Promoters are understood broadly and could include, but are not limited to, a partner, a family, a pastoral or spiritual care giver, a counselor, a religious figure such as Jesus, a community, or a new employer.

The purpose of this article is to share a dialogical self theory conceptualization and methodology that was utilized in the analysis of existential and religious dimensions in identity reconstruction among nineteen Swedish military personnel during the process of becoming civilians. This conceptualization and methodology has served to map, grid, and understand the evolution of self-narratives among the participants throughout a longitudinal research project carried out during 2013-2016. The combination of a psychological framework, such as the dialogical self, and theology may prove to become a fertile ground for individuals interested in self-identity work from the outlook of, for example, research, counseling, and pastoral or spiritual care. The interface between psychology and theology may also have social relevance since transition from military to civilian life affects a large number of service members and the communities within which they exist with existential issues or moral concerns that may be alleviated by theological and religious/spiritual approaches to their struggles. The ways in which service members deal with self-identity issues in transition will have impacts on their social environments. 
The central research question of this article is: How may theology aid selfreorganization in the transition from military to civilian life when employed through a dialogical self methodology? This article will present one longitudinal case study analysis of Private First Class Adam, who is himself one of more than six million members of the formerly state run Evangelic-Lutheran Church of Sweden and who aspires with such refined focus to demonstrate depth and details of the methodology utilized in the analysis. Adam had served for about two years in the Swedish Armed Forces, including a deployment to Afghanistan. Additionally, the results of the analysis will be brought into a psychological and theological discussion with related research. This article will continue with a conceptualization of a dialogical self and a narrative methodology.

\section{Conceptualization of a Dialogical Self}

Hermans and Gieser (2012) described Dialogical Self Theory as a bridging theory wherein a variety of theories, research traditions, and practices meet in order to build new and unexpected linkages. A dialogical idea of the self combines what Hermans \& Hermans-Konopka (2010) conceptualize as traditional, modern and post-modern understandings of the self. This dialogical idea of the self describes it as an extension of its (military and civilian) cultures and societies and thus views the self as a "society of the mind" that includes a variety of voices, each of which having its own characteristics, tensions, conflicting ideas, and potentials for dialogue (Hermans, 2002, p. 147).

The psychological topography of the self is understood and described through I-positions, and it has been suggested that a dialogical self consists of two types of I-positions (Hermans, 2001a, 2001b). These I-positions are differentiated by whether they are linked to the internal or to the external domain of the self. I-positions within the internal domain of the self are located inside of a person (e.g., 'I as a happy person', 'I as an enjoyer of life'). I-positions within the external domain of the self are located outside of the person (e.g., the I-positions of my parents, the I-position of my child), even as these are internalized as parts of a self through the considerations of the perspectives of others (Jasper, Moore, Whittaker \& Gillespie, 2012). Based upon this perspective the theoretical framework of a dialogical self understands the self as an extension to its surroundings; the other is not outside of the self but rather an intrinsic part of it, and this point of view contrasts with classic theories which emphasize a dichotomy between the inner and the outer. The compilation of numerous I-positions resonates to the position repertoire of the multiplicity of the self (Hermans, 2001a, 2001b). Yet, unity is a central concept, and unity and continuity are achieved through the composite self, which is narrated by attributing I, me, or mine to positions that, and even if they are contradictory, nonetheless belong to the self (Hermans \& Hermans-Konopka, 2010). 
The classic definition of a dialogical self (Hermans, Kempen \& van Loon, 1992, p. 28) emphasizes the dimensions of space, situation, time, and relations between contrasting positions in the self:

The I has the possibility to move, as in a space, from one position to the other in accordance with changes in situation and time. The I fluctuates among different and even opposed positions. The I has the capacity to imaginatively endow each position with a voice so that dialogical relations between positions can be established.

The movement between I-positions within the position repertoire of the self could be understood as a process of positioning and re-positioning or counter-positioning. Diverse positions may from time to time escalate in tension or even clash with each other (Hermans \& Hermans-Konopka, 2010). The dialogical self may act to integrate and center such decentralizing movements of the self (Hermans \& Dimaggio, 2007). The challenges of such a dialogical exercise of the self may differ from person to person. This capacity can be easily exercised, or conversely suppressed by a vociferous I-position that downplays any attempts for conversation in preference of monologue. The dialogue of the self can be conducted between two internal I-positions (e.g., 'I as a helpful person' agrees with 'I as a believer'), between internal and external or extended I-positions (e.g., 'I as a helpful person' appreciates working with 'my caring co-workers') or between two external I-positions (e.g., 'my wife' enjoys spending time with 'my parents').

A composite self can increase dialogue, centering movements and integration in a number of ways. A conflict between two powerful I-positions of the self may produce much tension and friction and severely limit the capacity for dialogue, but the evolution of a third position can potentially unite such conflicting positions of the self by respectfully allowing for their differences. A group of I-positions can engage as a coalition of positions in the position repertoire to cooperatively work together and support shared desires, motives, and interests. Such a coalition may on the one hand become dominant and could potentially diminish the capacity for broader dialogue, or could on the other hand accelerate innovation of the self amid the necessity of addressing change (Hermans, 2003, 2008). Promoter positions serve as innovators of the self on a temporal level and may include real, remembered, anticipated or imaginary significant others. A teacher, parent, partner, spiritual leader, or religious figure, such as Jesus, may serve as a promoter and can be located within the external domain, but potentially also the internal domain as in the case of a deceased parent or of Jesus (Hermans \& Hermans-Konopka, 2010). Valsiner (2004) suggests that promoter positions can be recognized by a number of characteristics, such as openness toward the future and a potential to produce specialized and qualitatively different positions in the future self. Inherit in the openness is a capacity to integrate new and already existing positions. Promoter positions take a primary place in the position repertoire and have the capacity to reorganize the self toward a higher level of development. 
Meta-position is another concept of an important position for a dialogical self; metapositioning (sometimes described as meta-cognitive activity) allows for self-reflection from a bird's-eye perspective. According to Hermans \& Hermans-Konopka (2010) meta-positions have specific qualities and allow for a certain distance from other positions, although they may be attracted toward some positions more than others. Meta-positions provide the self with an outlook from a higher spatial altitude so that several positions can be observed simultaneously and their mutual relationships better seen. Meta-positions may permit meaningful linkages between several positions and can therefore have a unifying influence upon the self. The higher spatial altitude also allows for evaluation of the viewed positions and their organization, and thus a broader basis for decision making and finding one's direction in life. Alternate meta-positions may emerge depending on time and context, and this implies that every meta-position has its own horizons and thereby its own limitations.

\section{The self as a dialogical narrator}

A promising path in the attempt to advance self-identity work in transition from military to civilian life is a theoretical framework and methodology that can take into account conflict, tension, contradiction, and poly-vocality in the storied self of a service member without reducing it to a single personal narrative of ego-identity development (Grimell, 2017a). The dialogical self is, from a narrative point of view, a dialogical narrator with several I-positions each having its own unique character and corresponding story to tell depending upon time and context (Hermans et al., 1992). Such characters narrated by various I-positions become united, likely with tension and numerous plotlines, in a complex, narratively structured story of who I am that, to varying degrees, is prompted to change during any given transition. As service members leave active service, their selves may require reorganization as new situations in their lives are encountered. "In the case of a transition, the self is confronted with a new, unfamiliar, or even threatening situation that requires an adaption or reorganization of the self" (Hermans \& Hermans-Konopka, 2010, p. 239). A transition therefore calls for the adaption of potentially esteemed I-positions, and most likely the formation of new ones. A transition and its inherent adaptations necessitate at least some degree of reorganization of positions in order to maintain or create a functional dialogical capacity of the self amid a new life situation (Hermans, 2004). Thus a reorganization of I-positions corresponds to a reorganization of stories, and this implicates that service members have to reformulate their personal narratives amid transition as the military characters of their selves lose their military context and audience. This can become a taxing, and even an existential process since such questions as who am I?, where am I going?, and what is my place in the world? all call for answers in regards to the reformulation of narrative identities and to the reorganization of I-positions. 


\section{Method}

Private First Class Adam's longitudinal case study example was derived from a research project approved in 2013 and designed to investigate existential and religious dimensions in identity reconstruction among voluntarily released Swedish service members amid their transition from military into civilian life. The project included nineteen participants who were interviewed annually in three cycles spanning from 2013 to 2016 as they initiated, but not always fulfilled, processes to begin lives and reformulate identities in a Swedish civilian context. The objectives were to investigate transitional experiences, identity reconstruction, and existential/religious elements in the process. Throughout the project, some participants kept one foot anchored in part-time military service, or returned after a hiatus to a part-time military context, or, in some cases, even aborted the transition fully and returned to full-time active service. The narrative interviews were processed through a narrative methodology, which is a productive lens to utilize in the analysis of narrative identities and selves (Clandinin, 2013; Hermans \& Hermans-Jansen, 1995; McAdams, 2013; McAdams, Josselson \& Lieblich, 2002, 2006). The analysis was centered on how pre-existing and new narrative characters evolved and interacted across the repeated interviews (Slocum-Bradley, 2009). The concept of I-positions, derived from Dialogical Self Theory (Hermans \& Hermans-Konopka, 2010), proved to be a helpful approach to link narrative characters via I-positions to the self-identity work of the participants.

Private First Class Adam, referred to with a fictitious name but correct rank, was selected for this article as a case study example since he is an appropriate representation of the processual development among those within the sample who reorganized their self amid their transition through a hybrid civilian and military identity evolving through cooperation and dialogue between military and civilian positions with little to no tension at all, something which was rarely demonstrated. The case of Adam is therefore both representative and qualitatively unique because Adam was the only younger participant who narrated that he allowed God to exist in his life and who articulated a type of Christian karma-belief significant for the life that he lived.

\section{Participants}

The participants were informed about the study by a letter of information that introduced the background of the project (i.e. a need to gain knowledge about the process of transition among service members) and that described the purpose of the project, the number of interviews, the research ethics, and both the anonymity and formalities. The sample volunteered through a snowball sampling method (Noy, 2008; Polkinghorne, 2005). The letter of information also presented the researcher/ interviewer as a former officer in the Swedish Armed Forces, and this implicated that the participants knew me not only as a researcher with a stated research purpose 
but also as someone who had served. I experienced that my military background facilitated the interviews in regards to military cultural knowledge (Brunger et al., 2013; Mishler 1986, 2004).

The letter of information asked the participants to complete a response letter and return it and also served as the informed consent agreement. Additionally, the participants were required to suggest a time and place to conduct the first interview. There was a variation within the sample in regards to age, mission experience, rank, and regimental background. Most of the sample included service member aged between 23 to 35 years old. Three service members were female. Four service members had retired and were thus around 60 years old. The ranks ranged from Private First Class to Major. The majority of the sample consisted of Caucasian males and females.

Some of the details presented for Adam have been slightly altered or omitted to safeguard his anonymity (e.g., explicit information about regiment, unit, names of significant others, explicit studies, and explicit work place/tasks

\section{Interview protocol}

The same interview questions were employed over the project by repeated interviews based on a semi-structured design in order to cover stories of service, transition, relationships, identities, and existential concerns (Kvale 2007; Kvale \& Brinkmann 2009; van den Brand, Hermans, Scherer-Rath \& Verschuren 2014). ${ }^{2}$ The semi-structured design was preferable so as to cover topics in correspondence to the purpose of the project in comparison to an unstructured interview design. The semi-structured design allowed for specific follow up questions in response to the stories told by the participants. The questions were designed to open up the topics and allow the participants to construct answers in ways that they found meaningful (Riessman 1993; Webster \& Mertova 2007). The questions were formulated as openended questions, and the interview started with the question: "If you were to think for a while, in what way would you describe your life or service as a soldier or an officer?" The participants were encouraged through this interview method to tell their own stories in their own ways (Clandinin \& Connelly, 2000; Crossley 2000). All of the interviews were transcribed verbatim into complete transcripts in Swedish (transcripts can be provided to other researchers per request).

A research project with a qualitative interview design as the likes of this aspires to describe individual processes amid transition from a narrative point of view. Mishler (1991) and Ganzevoort (1998) have suggested that narrative research may score higher on validity (i.e. to measure what is intended to be measured) depending on

2 For the semi-structured interview protocol see Appendix 1. 
the quality of the data collection. This implicates posing interview questions that address the topic of investigation in relevant ways. However, reliability in terms of replication may be more difficult to capture within a narrative study (Grimell, 2018).

The interviewer, who also authored this article, feels that his military cultural knowledge facilitated the interviews (cf. Brunger et al., 2013; Mishler 1986, 2004). Yet, since I also have personal experiences of transition from military to civilian life, I felt compelled to write down my own stories and thereby identify my influential I-positions prior to the research project in the interest of further advancing my growing awareness of my personal story. This was intended to safeguard the interviewees' stories of transition by isolating their stories as much as possible from my own transition; specifically, it was an effort to limit the variables (for a full discussion of this process and the researcher's positions, see Grimell, 2018).

\section{Narrative analysis}

The first phase: The transcripts and digital recordings from the three interviews (Time 1-3) were used in close rereading and relistening to summarize the content and abstract story lines, themes, and tones of the interviews so as to garner a global picture of Adam's self-reorganization during transition from military to civilian life (Clandinin, 2013; Clandinin \& Connelly, 2000; McAdams, 1988, 1997). This "global reading” was summarized in a short story for every transcript (Ganzevoort, 1998, p. 28).

The second phase: Storied descriptions within the interviews were considered to represent identity claims of different characters, voices, or points of view populating Adam's self at that time (McAdams, 1997; McAdams et al., 2006; Mishler, 1986, 2004; Sarbin, 1986), and these were interpreted as I-positions of the self (Hermans et al., 1992, Hermans, 1996, 2001a). A qualitative software analysis program (i.e. Atlas. ti) was used in the analytical process to code and keep track of the narrative evolution of characters, voices, and points of view in the transcripts.

The third phase: The rearrangement of preexisting and new characters, voices, and points of view were compared and understood as the actual process of reorganization of I-positions across the interviews 1-3. The movement, dialogue, potential contradiction, tension, and/or conflict between the narrative characters, voices, and points of view expressed in the storied accounts of the interviews demonstrated the self-identity work (Hermans, 1999, 2003). The concepts from a dialogical framework were then used to interpret the evolution of Adam's narrative self amid transition. 


\section{Results}

\section{Background}

Private First Class Adam was in his early twenties when he joined the Swedish Armed Forces. He served actively for approximately two years as a radio operator (at a squad level), including a deployment to Afghanistan. After Afghanistan, personal stagnation followed his service, which included a daily repetition of exercises, routines, and knowledge that he felt he already knew more than well. There was also some tension within his group that rendered him less interested in continuing with active service. On the other hand, Adam experienced a growing interest to pursue academic studies. After a period of time, Adam therefore decided to leave active service; however, since he had performed well across service, he was offered an opportunity to continue as a part-time serving soldier in the regiment. Adam agreed to this as he enjoyed the applied field exercises.

Adam was a member in the Evangelical-Lutheran Church of Sweden; even as he did not frequently attend sermons, he did enjoy attending on special occasions, such as weddings. Adam's belief in God was shaped during confirmation by a minster who had explained to Adam that he should not force himself to believe in God but instead allow God to exist in his life. Adam testified:

It is how I see it, too, I believe. I allow Him to exist, just like that; He exists indeed, and I allow it. It is what I see as confirmation also that I, it does not mean that I am a huge believer but instead that I believe that God exists...

Over the annual interviews with Adam, a number of positions or voices were narrated and testified to have existed for a long time in his self, and those were: 'I as a son,' 'I as happy,' 'I as an enjoyer of life,' 'I as helpful,' and 'I as allowing God to exist.' Those positions had populated Adam's self for a long time and had their own history. Meanwhile, other positions in the interview narratives, such as ' $\mathrm{I}$ as a soldier,' 'I as a student,' and 'I as an employee' were considered as having been more recently added to Adam's position repertoire, yet they too had already evolved their own specific characters and stories.

\section{The first interview 2013 (T1)}

Adam had left active service just a few days prior to the first interview, and as the interview was conducted, his military character of a soldier populated much of the narrative as the military story, and some transitional experiences, were described in reference to his being some days post exit. Adam's military character described tight bonds between battle buddies, camaraderie, and deep insights about how the mind and the body had reacted during extreme exercises and a posting in a war zone such as Afghanistan. Adam narrated that there existed a dichotomy between those who 
had served and those who had not, and this was particularly salient in regards to Afghanistan, as he testified beginning with a sigh:

I had realized long ago that a person never understands something before he does it in person, and it is obvious, so that it is sad, I think, about everything really. If a person doesn't know then a person should believe the newspaper, and the newspaper prints maybe $10 \%$ of the reality. It is unfortunately such that actually a person should not talk too much about it... I share indeed with those who have, I talk in fact about it with those who I have served with, those who know more. It isn't really such that I bring up that I have been in Afghanistan and it was like this and that. Often it is in fact that they will pose questions and then yes, I answer as well as I can and what I think about what they ask about...

Adam's prospects for the nearest future, being some days post exit, were quite loosely formulated, and when considering the coming months post exit, he revealed that he was about to conduct a long journey across Europe and America with a battle buddy who had already transitioned to a civilian life. This was a course of action that collaborated with many of Adam's internal positions, such as 'I as happy' and 'I as an enjoyer of life' as well as 'I as a soldier,' and Adam recounted in regards to the journey:

It feels totally wonderful in fact, it feels simple, it really is to release and to go. It is also just to follow with the road so we have actually not decided anything, instead we just have, we are soldiers and we will hold, and all time in between, we can do precisely what we will, and we take it as it comes, and it is in that way really fun.

Adam also introduced a potential, yet embryonic student voice in the interview narrative as his plan was to begin university sometime after the journey. Adam recounted:

I'm drawn to physics; that is what I want to study. I believe it was for that reason that I chose to be a radio operator also... I would really like to develop a, like, a new radio or something like that.

In summation, Adam's self-reorganization amid transition was only entering an early phase and still revolved much around his military character. Even so, 'I as happy' and 'I as an enjoyer of life' were taking lead roles in cooperation with his military character as they looked forward to taking a long road-trip. Meanwhile, a new voice was narrated in regards to a desire to follow this adventure with higher education.

\section{The second interview 2014 (T2)}

As we met for the second interview in the following year, Adam had just begun university studies. The student character was now shaped through interactions within the academic context (including student peers) and had its own story to tell that served as an identity claim. Adam enjoyed studying and was also working part-time to earn extra money in a restaurant near the campus, which also correlated a new position in his position-repertoire ('I as an employee'). 
Adam had also served some weeks over the recent year in an applied field exercise, describing the blend of full-time studies and part-time military service as: "A life-form which makes a good balance.” Adam appreciated part-time service and recounted:

We are fast in the preparation of the exercise, how to execute orders; you still have it in the back of your mind, and that is what I think is fun. You are supposed to have fun at work, which is what is good.

New to the situation was that during the interview, Adam engaged meta-cognitive activities that were attracted to his identity claims of a student and of a part-time serving soldier, but not to the previous context of full-time service. Adam testified:

Just the thought that I lived there [he is referring to where he was formerly stationed as a full-time soldier], it is really not the world's most fun place to live in, or so a person cannot say, or it is actually not so many people there, but it is more fun when I was there just for a bit, it made it more fun in that way, that I got a different perspective on it... so yeah, I believe that it was, was so far away. If I had had friends then I think that it could have been easier, absolutely, yeah. Now I cannot really say that I didn't have friends up there, but it was not so that I meant that everything had become the military way of thinking, definitely not. On the weekends, we had fun together and such, but I believe that it can be that I was a bit far away, I believe in any case it wasn't that. The bigger part was in fact that it was many group meetings but, I don't really know... tough to explain and say it. Now it is that it is cool to come up and perform these practices here...

Additional meta-cognitive activities in regards to Adam's deployment to Afghanistan also first manifested in the second interview, and these employed several points of view that included, among others, the external I-positions of Adam's parents ('the I of my father' and 'the I of my mother'). Sometime prior to his deployment, Adam and his parents had to prepare a document in regards to potential death in the line of duty; this document literally laid out a plan for his own church funeral if he did not survive. Adam demonstrated a more layered and complex bird's eye perspective upon the deployment as he recounted:

Well, from Afghanistan I thought, I have always, first like this I have always thought that we were glad for what we have, so like I always think, but it became more clear in Afghanistan... well not so that I have valued life more, after having had seen the paper, it was really just then when I should sign the thing I had discussed with my parents so there, home, yeah, ok, now shall we talk about my burial; it was indeed not so cool for my parents either... It was not really so dangerous, more like what should be done and such, and then they get a thought about my death, it was indeed that, I don't know, it was yes, it was a tough situation... Yes. And I thought it was, I am a bit many-sided, I enjoy to be in the garden and I don't like roses, so that I said that if, when I die I do not want to have roses on my grave, on my, yeah, on my coffin, I want to have, I said that I want to have coltsfoot flowers... yeah, and then we said in jest, yeah, then you should not die in the fall [coltsfoot is among the earliest of spring flowers], to lighten it up a little... Mom thought it was tough, more so than my father. 
In summation, Adam's self-reorganization had evolved over the recent year, and new to the interview narrative was the emerging identity of a student and an employee at a restaurant near the campus. The bird's eye perspective was also new and demonstrated layered complexities in contrast to the first interview. This metapositioning illustrated to be attracted to a life now mainly lived within a civilian context yet partly in a military context. 'I as happy' and 'I as an enjoyer of life' demonstrated to navigate well both in a civilian context and in a military context in consideration of the reformulated conditions for service.

\section{The third interview 2015 (T3)}

During the third and final interview, Adam was two years post exit of full-time service, albeit still employed part-time as a soldier to amass some weeks of service per year. Adam testified that parts of his military identity, earned through military service, aided him in his civilian life and as a student. This suggests that the character of a soldier was allowed to make dialogue with preexisting and emerging positions more rooted in civilian life. Adam recounted:

Much with structure has helped me even today. Efficiency, I would also like to say was given to me by the Armed Forces. When it is demanded I have an efficient position which is peaceful to have, that I can position within this rather easy. That you can have a position where you must work hard and then it's allowed to become a little imperfect as long as it's still right... Yeah, but for example, if someone is going to clean, then there are different ways to clean up, like one can do it fast or a person can do it more meticulously or like a person can just do it well. There are many different degrees. And by structured, I mean to be able to decide for oneself to lay out a plan with things that apply to training, for example, and also studies.

Adam's student character had evolved, and even more of his life was centered upon his studies and on being a part of the academic community. Yet Adam restricted himself from not participating much in different student associations and parties, as he prioritized his studies. Adam stated that what drove him forward in his life and studies was "to be happy and to have fun," which illustrated a cooperative spirit between 'I as a student,' 'I as happy,' and 'I as an enjoyer of life.'

One position that had been with Adam for a long time was 'I as helpful,' and this was "a big part of who I am" according to Adam. This position of a helpful, unselfish, and friendly character and thus approach to life was given plenty of space in the third interview narrative wherein Adam described a type of karma-belief:

I believe a lot in the choices a person makes and definitely that it indeed changes greatly the course of action, how life unfolds, also which roads one takes, sculpts new roads but that, in the end, leads them often to where the person started such that, there exist different situations which a person has surely thought so here: yeah, this place was a little strange, why does this happen and why right now? I don't have any deep belief, I shouldn't say, nonetheless if I should come 
to a belief then I believe strongly that, what should I say, karma, and I believe in fact that it's a big thing, that it's otherwise not seen, that I believe that even though it can take a long time, it comes back some time. It becomes so. It's, well, what I believe in... I haven't gone so deep into the belief, but I believe anyway that it, it feels strange what karma really is, and, if you do something bad, it will surely hit back, it's a little so... I don't invest so much thought in beliefs, but I feel simply that if it there's something I should believe in, then it is karma.

Adam's personal karma-belief included a specific responsibility for nature and his fellow humans so that he would not allow himself to violate anyone or anybody, and instead treated these entities with sincere friendship and honesty.

In summation, Adam's self-reorganization had evolved further with new civilian positions growing more salient as narrative characters in the stories he told. His internal positions of 'I as happy' and 'I as an enjoyer of life' collaborated well not only with these new positions of the self but also with the position of a part-time serving soldier. Adam's meta-cognitive activities invited preexisting and new points of view into the dialogue, wherein the 'karma-belief position' was growing within his position-repertoire and especially prone to cooperate with 'I as helpful.'

\section{Discussion}

Adam's longitudinal self-identity work evolved through emerging civilian narrative characters such as 'the student' and 'the restaurant employee' located within civilian and academic contexts. Even so, the military character was allowed space and voice in the reorganization of positions amid transition, although Adam also distanced himself distinctly across time from the contextual disadvantages of full-time service. Yet Adam demonstrated dialogical capacity over the time of the interviews, and his self-narratives accommodated poly-vocality as the interviews were populated by several I-positions, each which had its own unique character with corresponding story to tell depending upon time and context (Hermans et al., 1992; Hermans, 1996, 1999). Moreover, Adam's internal positions (e.g., 'I as happy', and 'I as an enjoyer of life') demonstrated to cooperate better with the emerging positions of a student, employee, and part-time serving soldier than with the position of a full-time serving soldier within a military context. The student position became Adam's promoter position amid transition, and as such it illustrated openness to the future self and had a capacity to integrate already existing and new positions, such as 'I as a soldier' and 'I as an employee.' His student peers, the wider academic community within which he studied, and his employer at the restaurant all served as promoters of the evolution of this position, and this provides a contrast to a growing body of research presenting the difficulties that service members experience as they transition from military to civilian life through academia as students (Elliott, Gonzalez \& Larsen, 2011; DiRamio, Ackerman \& Mitchell, 2008; Figley \& Leventman, 1980; Pellegrino 
\& Hoggan, 2015; Persky \& Oliver, 2011; Ruman, 2010; Ruman \& Hamrick, 2010; Zinger \& Cohen, 2010; Wheeler, 2012; Whiteman, Barry, Mroczek \& MacDermid Wadsworthet, 2013). Whereas many of these reveal struggles with a military/civilian dichotomy, conflicts by cultural clashes, and/or a sense of not fitting into the new context, Adam did not narrate any such hardships, which thereby suggests that there is also the possibility of experiencing support, dialogue, and self-identity evolution amid transition from military to civilian life via academia as a student.

Adam's meta-cognitive activities were particularly illustrated in the second and third interviews, and this development of accentuated self-reflection resonates with dialogical research that specifically investigates narrative processes of innovation of the self. Gonçalves and Ribeiro (2012) have, through their research on metapositions, found a linkage or relation between transforming self-narratives and meta-positioning, thus suggesting that a reconceptualization of a self-narrative involves a meta-position that articulates a past position (e.g., Adam's position of a former full-time serving soldier) and emerging positions (e.g., student, employee, and karma-position). The results of this study suggest, in line with Gonçalves and Ribeiro (2012) and Grimell (in press), that meta-positioning has, in addition to a developmental function, a unifying, executive, and liberating function, and that this duality implicates that through the continuation of meta-positioning involved in selfreorganization, a dis-identification with the past I-position occurs side by side with a growing identification with emerging ones.

Adam allowed God to exist in his life, and in doing so, he confirmed his believerposition and faith in a transcendent dimension. Meanwhile Adam's lived religion was more-so about doing good things for others, and by doing these good things, a positive chain reaction was initiated and/or sustained. This karma-position was central in Adam's life and the way through which he lived his belief and religion (Ganzevoort \& Roeland, 2014; McGuire, 2008). Here the approach of how religion is lived, rather than constituted by institutional religion and manifested by church attendance, becomes a fruitful way to understand how Adam's belief was expressed in a specific way of thinking and acting. The internal position 'I as helpful' was particularly prone to cooperate with this karma-position and was the internal agent in Adam's lived religion. However, when considering military service and deployment to conflict zones, it is suggested that such lived religion through a religious/spiritual idea of doing good as one part within a greater chain reaction may in fact increase the risk of spiritual and/or moral conflict, damage, or injury in the self depending upon how military service evolves for a service member. Such a suggestion is in resonance with recent research on spirituality and trauma among veterans by Koenig, Boucher, Oliver, Youssef, Mooney, Currier, \& Pearce (2017). In Adam's case, his deployment in Afghanistan did not radically go against his core belief as manifested 
through his lived religion of doing good things for others. His unit was not involved in combat, and the deployment was calm in consideration of being in a conflict zone. So Adam's perception of his deployment was that he had helped and aided the Afghans to live their lives more freely through his military presence. In this way, his lived religion, karma-position, and internal position as helpful were all in resonance with his military I-position and current experiences of deployment. This may not, however, be the case for other service members with a similar religious/ spiritual psychological topography as Adam. As recounted in another study, Vincent, a former military service member suffering from severe posttraumatic stress disorder (PTSD), gives voice to another implication of military service and deployment in consideration of a similar psychological topography (Grimell, 2016a). Vincent was a Catholic, and during early adulthood his Christian ethics grew steadfast. His faith in God was of a personal character, lived and experienced in regular life rather than in church. When Vincent was eighteen, he joined the British Royal Navy and later became an officer and was involved in combat during military operations in Ireland and throughout the entire Falklands war. However, that war also became the turningpoint for Lieutenant Commander Vincent. He began to feel dirty and could not look at himself in the mirror anymore. He left active service but kept a position as a reserve officer. He grew a beard to change his appearance. The civilian life became a struggle for Vincent, and he felt empty. He narrated that he had lost direction in life. Vincent also lost his relationship with God, or using his own words "I left God because I lost myself." He did not think anyone could ever love him, nor could God after all that he had done in combat. A number of years post exit, he married and became a father, and also nurtured an academic career, but Vincent eventually broke down and was, as a result, diagnosed with fatigue syndrome. Sometime later, he was diagnosed with post-traumatic stress disorder (PTSD). In addition to the struggles of fatigue syndrome and PTSD, a major psychological issue was related to his self-identity. Vincent kept asking himself "Who am I?" (Grimell, 2016a, p. 73). As the condition, confusion, and frustration grew worse, Vincent tried to take his own life several times. However, during the many years of treatment that followed his psychiatric and psychological condition, Vincent's relationship with God began to grow again, and he slowly started to perceive the fatigue syndrome, PTSD, and all of that which had followed post exit as a form of salvation. Vincent testified that he had been rescued by God and that God had given him another chance to live a life worth living.

Vincent's case illustrates how the dark impact of war and combat may shape the military identity in such destructive ways so that the contrast between himself as a Christian and an ethical person versus what he had become during military service became overwhelming and unbearable (also see Brock \& Lettini, 2012; Bryan, Graham \& Roberge, 2015; Koenig et al., 2017; Kopacz \& Connery, 2015; Rambo, 2010; Wortmann et al., 2017). His dialogical capacity of the self fundamentally 
collapsed. The gulf between who Vincent once was (i.e., preexisting I-positions) and who he had become (i.e., military position) was perceived as an unbridgeable gulf within the self. However, during the psychiatric and psychological treatment, the idea of a forgiving God slowly began to function as a promoter that worked through Vincent's believer-position and gradually made it possible for Vincent to innovate his self on a temporal level despite diagnoses and hardship. The vitalized position of 'I as a believer in God' served as a promoter position with an openness toward the future and was promoted by the idea of a God who had saved and rescued Vincent and gave him another chance to live life. The promoter position had the capacity to integrate already existing positions, even the dominant military position that had been so horribly traumatized. This suggests that 'I as a believer in God' was given a primary place in the position repertoire and reorganized Vincent's self toward a higher level of self-identity development. Vincent never recovered from PTSD, but his spiritual injury was healed, and he could live a life worth living (Ganzevoort, 2008).

There are some final suggestions for spiritual/religious leaders and practitioners to consider. Spiritual/religious leaders and practitioners may have crucial roles both in preparing service members for and in coping with the repercussions of enlistment and/ or deployment. Awareness of potential spiritual damages as a result of military service may in some ways help to prepare a service member and enlighten a healthier evolution of spiritual life. Furthermore, if discussion has already illuminated such a cooperative and supportive path, then it seems more probable that a service member may return to consult military chaplaincy for guidance and counseling. It is additionally important to remember that religious/spiritual leaders are themselves typically parts of larger religious communities, and recent research supports the collaboration between religious/spiritual leaders/communities and clinicians (Bobrow, Cook, Knowles \& Vieten, 2013; Wortmann et al., 2017). Continuing research is encouraged so as to advance the understanding of veterans through the lens of dialogical psychology (Grimell, 2016a, 2017a).

\section{Conclusion}

Articulated and salient religious/spiritual ethical positions, such as in the cases of Adam and Vincent, may potentially render service members spiritually vulnerable when or if such positions feel violated or transgressed in the line of duty. This transgression may create a spiritual injury in the self that impoverishes, disconnects, or even annihilates the dialogue between spiritual positions and military positions in the self, and even between spiritual positions and God or transcendent powers (Berg, 2011; Koenig et al., 2017; Wortmann et al., 2017). A distinct feature for a dialogical understanding of such a destructive evolution is that dialogue becomes suppressed by a monologue. It is moreover important to underscore that spiritual injury as it is understood here is related to ethics but is not a moral injury (or a psychological moral 
process of negotiation between different cultural positions in the self). It is instead a spiritual injury that damages or disconnects the spiritual capacity of the self.

Even though believer-positions may make service members spiritually vulnerable, believer- positions also accommodate a potential advantage for healing such a spiritual injury or disconnect. As in the case of Vincent, the believer-position can take the lead as a promoter-position with a capacity to re-activate dialogue and heal spiritual injuries without ignoring or denying the trauma and/or diagnosis as such but by instead allowing light to exist amid the darkness.

Two potential theological points of view or positions that may serve to nurture the development of promoter-positions and dialogue amid such trauma are forgiveness and acceptance as promoted by the idea of God or significant others (e.g., partner, family, religious/spiritual community, military chaplain, or counselor). Even if a former service member cannot fully forgive what he or she has done in the line of duty, he or she may potentially embrace the idea that higher powers or God may forgive, and thereafter integrate this idea into the self-identity work to eventually facilitate a resumption of dialogue and spiritual healing. In a secular context where God and higher powers appear to be difficult to embrace, the process of forgiveness may be alternatively formulated with an existential terminology of acceptance (Tillich, 2014). Even if a former service member cannot fully accept what he or she has done, he may potentially accept that he is accepted by others or something bigger than oneself such as a community or nature. Through acceptance of the idea that one is accepted (Tillich, 2014), dialogue may take the place of monologue and then potentially bridge the gulf in the self and allow for spiritually-oriented positions and traumatized military positions to live side by side despite the existence of invisible wounds.

\section{References}

Adler, A. B., Zamorski, M., \& Britt, T. W. (2011). The psychology of transition:

Adapting to home after deployment. In A. B. Adler, P. B. Bliese, \& C. A. Castro (Eds.), Deployment psychology: Evidence-based strategies to promote mental health in the military (pp. 153-174). Washington, DC: American Psychological Association.

Bélanger, S. A. H., \& Moore, M. (2013). Public opinion and soldier identity: Tensions and resolutions. In A. B. Aiken, \& S. A. H. Bélanger (Eds.), Beyond the line: Military and veteran health research (pp. 103-120). Montreal and Kingston: McGill-Queen's University Press.

Berg, G. (2011). The relationship between spiritual distress, PTSD and depression in Vietnam combat veterans. Journal of Pastoral Care and Counseling, 65(1-2):6:1-11.

Bobrow, J., Cook, E., Knowles, C., \& Vieten, C. (2013). Coming all the way home: Integrative community care for those who serve. Psychological Services, 10(2), 137-144.

Bragin, M. (2010). Can anyone here know who I am? Co-constructing meaningful narratives with combat veterans. Clinical Social Work Journal, 38(3), 316-326. 
Brunger, H., Serrato, J., \& Ogden, J. (2013). "No man's land": the transition to civilian life. Journal of Aggression, Conflict and Peace Research, 5(2), 86-100.

Bryan, C. J., Graham, E., \& Roberge, E. (2015). Living a life worth living: Spirituality and suicide risk in military personnel. Spirituality in Clinical Practice, 2(1), 74-78.

Buell, S. D. (2010). Life is a cruise: What does it mean to be a retired naval officer transitioning into civilian world? (Doctoral dissertation, University of St. Thomas, Minnesota, United States of America).

Clandinin, J. D. (2013). Engaging in narrative inquiry. Walnut Creek, CA: Left Coast Press, Inc.

Clandinin, J. D., \& Connelly, M. F. (2000). Narrative inquiry: Experience and story in qualitative research. San Francisco: A Wiley Imprint.

Crossley, M. L. (2000). Introducing narrative psychology: Self, trauma and the construction of meaning. Philadelphia: Open University Press.

DiRamio, D., Ackerman, R., \& Mitchell, R. L. (2008). From combat to campus: Voices of studentveterans. NASPA Journal, 45(1), 73-102.

Drops, G. J. (1979). Change in self-concept and identity during a time of mid-life transition (Doctoral dissertation, the Union for Experimenting Colleges and Universities, Union Graduate School West, San Diego, United States of America).

Elliott, M., Gonzalez, C., \& Larsen, B. (2011). U.S. military veterans transition to college: Combat, PTSD, and alienation on campus. Journal of Student Affairs Research and Practice, 48, 279296. Doi:10.2202/ 1949-6605.6293

Figley, C. R., \& Leventman, S. (1980). Introduction: Estrangement and victimization. In C. R. Figley \& S. Leventman (Eds.), Strangers at home: Vietnam veterans since the war (pp. xxixxxi). New York: Praeger.

Ganzevoort, R. R. (1998). Reading by the lines: Proposal for a narrative analytical technique in empirical theology. Journal of Empirical Theology, 11(2), 23-40.

Ganzevoort, R. R. (2008). Scars and stigmata: Trauma, identity and theology. Practical Theology, $1(1), 19-31$.

Ganzevoort, R. R., \& Roeland, J. H. (2014). Lived religion. The praxis of practical theology. International Journal of Practical Theology, 18(1), 91-101.

Gonçalves, M. M., \& Ribeiro, A. P. (2012). Narrative processes of innovation and stability within the dialogical self. In H. J. M. Hermans, \& T. Gieser (Eds), Handbook of dialogical self theory (pp. 301-318). New York: Cambridge University Press.

Grimell, J. (2015). A transitional narrative of military identity: Eric's story. International Journal for Dialogical Science, 9(1), 135-157.

Grimell, J. (2016a). The story of the self in the aftermath of crisis: A case study. Journal of Constructivist Psychology, 29(1), 66-79.

Grimell, J. (2016b). Existential spiritual life among Swedish service members in transition: Marking out trends. Spirituality in Clinical Practice, 3(3), 208-219.

Grimell, J. (2017a). Advancing an understanding of selves in transition: I-positions as an analytical tool. Culture \& Psychology, 0(0), 1-22.

Grimell, J. (2017b). Self-reorganization in transition from military to civilian life: Maria's way. Mental Health Family Medicine, 13, 544-553. 
Grimell, J. (2018). Reconsidering the uniform: Existential and religious identity reconstruction among Swedes after military service (Doctoral dissertation, Vrije Universiteit Amsterdam, The Netherlands). Zürich, Switzerland: LIT Verlag.

Haynie, J. M., \& Shepherd, D. (2011). Toward a theory of discontinuous career transition; Investigating career transitions necessitated by traumatic life events. Journal of Applied Psychology, 96(3), 501-524.

Hermans, H. J. M. (1996). Opposites in a dialogical self: Constructs as characters. Journal of Constructivist Psychology, 9, 1-16.

Hermans, H. J. M. (1999). Dialogical thinking and self-innovation. Culture and Psychology, 5(1), 67-87.

Hermans, H. J. M. (2001a). The dialogical self: Toward a theory of personal and cultural positioning. Culture \& Psychology, 7(3), 243-281.

Hermans, H. J. M. (2001b). The construction of a personal position repertoire: Method and practice. Culture and Psychology, 7(3), 323-365.

Hermans, H. J. M. (2002). The dialogical self as a society of mind: Introduction. Theory \& Psychology, 12(2), 147-160.

Hermans, H. J. M. (2003). The construction and reconstruction of a dialogical self. Journal of Constructivist Psychology, 16, 89-130.

Hermans, H. J. M. (2004). Introduction: The dialogical self in a global and digital age. Identity: An international Journal of Theory and Research, 4, 297-320.

Hermans, H. J. M. (2008). How to perform research on the basis of dialogical self theory? Introduction to the special issue. Journal of Constructivist Psychology, 21, 185-199.

Hermans, H. J. M. (2012a). Applications of dialogical self theory: New directions for child and adolescent development. Jossey-Bass, San Francisco: Wiley Periodicals, Inc.

Hermans, H. J. M. (2012b). Between dreaming and recognition seeking: The emergence of dialogical self theory. Lanham, Maryland: University Press of America, Inc.

Hermans, H. J. M. (2013). The dialogical self in education: Introduction. Journal of Constructivist Psychology, 26(2), 81-89.

Hermans, H. J. M., Kempen, H. J. G., \& van Loon, R. J. P. (1992). The dialogical self: beyond individualism and rationalism. American Psychologist, 47, 23-33.

Hermans, H. J. M., \& Hermans-Jansen, E. (1995). Self-narratives: The construction of meaning in psychotherapy. New York: The Guilford Press.

Hermans, H. J. M., \& Dimaggio, G. (2007). Self, identity, and globalization in times of uncertainty: A dialogical analysis. Review of General Psychology, 11(1), 31-61.

Hermans, H. J. M., \& Hermans-Konopka, A. (2010). Dialogical self theory: Positioning and counter-positioning in a globalizing society. New York: Cambridge University Press.

Hermans, H. J. M., \& Gieser, T. (Eds.). (2012). Introductory chapter: History, main tenets and core concepts of a dialogical self theory. In H. J. M. Hermans, \& T. Gieser (Eds.), Handbook of dialogical self theory (pp. 1-28). New York: Cambridge University Press.

Jasper, C. A., Moore, H. R., Whittaker, L. S., \& Gillespie, A. (2012). Methodological approaches to studying the self in its social context. In H. J. M. Hermans \& T. Gieser (Eds.), Handbook of dialogical self theory (pp. 319-334). New York: Cambridge University Press. 
Koenig, H. G., Boucher, N. A., Oliver, J. P., Youssef, N., Mooney, S. R., Currier, J. M., \& Pearce, M. (2017). Rationale for spiritually oriented cognitive processing therapy for moral injury in active duty military and veterans with posttraumatic stress disorder. The Journal of Nervous and Mental Disease, 205(2), 147-153.

Kvale, S. (2007). Doing interviews. London: Sage.

Kvale, S., \& Brinkmann, S. (2009). Den kvalitativa forskningen [The qualitative research] ( ${ }^{\text {nd }}$ ed.). Lund, Sverige: Studentlitteratur AB.

Litz, B. T., Stein, N., Delaney, E., Lebowitz, L., Nash, W. P., Silva, C., \& Maguen, S. (2009). Moral injury and moral repair in war veterans: A preliminary model and intervention strategy. Clinical Psychology Review, 29(8), 695-706.

McAdams, D. P. (1988). Power, intimacy and the life story: Personological inquiries into identity. New York: The Guilford Press.

McAdams, D. P. (1997). The stories we live by: Personal myths and the making of the self. New York: The Guilford Press.

McAdams, D. P. (2013). The redemptive self: Stories Americans live by. New York: Oxford University Press.

McAdams, D. P., Josselson, R., \& Lieblich, A. (Eds.). (2002). Turns in the road: Narrative studies of lives in transition. Washington, DC: American Psychological Association.

McAdams, D. P., Josselson, R., \& Lieblich, A. (Eds.). (2006). Identity and story: Creating self in narrative. Washington, DC: APA Books.

McGuire, M. (2008). Lived religion: Faith and practice in everyday life. New York: Oxford University Press.

Mishler, E. G. (1986). The analysis of interview-narratives. In T. R. Sarbin (Ed.), Narrative psychology: The storied nature of human conduct (pp. 233-255). Westport, CT: Praeger.

Mishler, E. G. (1991). Research interviewing: Context and narrative. Cambridge: Harvard University Press.

Mishler. E. G. (2004). Storylines: Craftartistis' narratives of identity. Cambridge, MA: Harvard University Press.

Brock, R. N., \& Lettini, G. (2012). Soul repair: Recovering from moral injury after war. Boston, MA: Beacon Press.

Noy, C. (2008). Sample knowledge: The hermeneutics of snowball sampling in qualitative research. International Journal of Social Research Methodology, 11(4), 327-344.

Pellegrino, L., \& Hoggan, C. (2015). A tale of two transitions female military veterans during their first year at community college. ADULT LEARNING, 26(3), 124-131.

Persky, K. R., \& Oliver, D. E. (2011). Veterans coming home to the community college: Linking research to practice. Community College Journal of Research and Practice, 35, 111-120.

Polkinghorne, D. E. (2005). Language and meaning: Data collection in qualitative research. Journal of Counseling Psychology, 52(2), 137-145.

Rambo, S. (2010). Spirit and trauma; A theology of remaining. Louisville, KY: Westminister John Knox Press.

Riessman, K. C. (1993). Narrative analysis. London: Sage. 
Rosenberg, S. D. (1993). The threshold of thrill: Life stories in the skies over Southeast Asia. In M. G. Cooke, \& A. Woollacott (Eds.), Gendering war talk (pp. 43-66). New Jersey: Princeton University Press.

Rumann, C. B. (2010). Student veterans return to community college: Understanding their transitions (Doctoral dissertation). Available from ProQuest Dissertations and Theses database. (AAT 3403830)

Rumann, C. B., \& Hamrick, F. A. (2010). Student veterans in transition: Re-enrolling after war zone deployments. Journal of Higher Education, 81(4), 431-458.

Sarbin, T. R. (Ed.). (1986). The narrative as a root metaphor for psychology. In T. R. Sarbin, (Ed.), Narrative psychology: The storied nature of human conduct (pp. 3-21). Westport, CT: Praeger.

Savion, S. M. (2009). How do retired officers start anew in civilian society? A phenomenological study of life transition (Doctoral dissertation, The George Washington University, Washington, United States of America). Retrieved from http://sunzi.lib.hku.hk/ER/detail/hkul/4354853

Tillich, P. (2014). The courage to be ( $3^{\text {rd }}$ ed.). New Haven, CT: Yale University Press.

Thornborrow, T., \& Brown, A. D. (2009). Being regimented: Aspiration, discipline and identity work in the British parachute regiment. Organization Studies, 30(4), 355-376.

Valsiner, J. (2004, July 11-15). The promoter sign: Development transformation within the structure of the dialogical self. Paper presented at the Biennial Meeting of the International Society for the Study of Behavioral Development, Ghent.

van den Brand, J., Hermans, C., Scherer-Rath, M., \& Verschuren, P. (2014). An instrument for reconstructing interpretation in life stories. In R. R. Ganzevoort, M. de Haardt, \& M. SchererRath (Eds.), Religious stories we live by: Narrative approaches in theology and religious studies (pp. 169-180). Leiden, Netherlands: Brill.

Webster, L., \& Mertova, P. (2007). Using narrative inquiry as a research method: An introduction to using critical event narrative analysis in research on learning and teaching. London: Routledge Taylor \& Francis.

Whiteman, S. D., Barry, A. E., Mroczek, D. K., \& MacDermid Wadsworth, S. (2013). The development and implications of peer emotional support for student service members/veterans and civilian college students. Journal of Counseling Psychology, 60(2), 265-278.

Wortmann, J. H., Eisen, E., Hundert, C., Jordan, A. H., Smith, M. W., Nash, W. P., \& Litz, B. T. (In press). Spiritual features of war-related moral injury: A primer for clinicians. Spirituality in Clinical Practice, 4(4), 249-261.

Yanos, R. C. (2004). Perceptions of transition to civilian life among recently retired Air Force officers (Doctoral dissertation, University of Maryland, College Park, United States of America). Retrieved from http://drum.lib.umd.edu/handle/1903/2321

Zinger, L., \& Cohen, A. (2010). Veterans returning from war into the classroom: How can colleges be better prepared to meet their needs. Contemporary Issues in Education Research, 3(1), 39-51. 


\section{Appendix I}

\section{Interview Guide (translated from Swedish)}

(A) Questions to grasp the central military story line

- If you were to think for a while, in what way would you describe your life as a soldier or an officer?

- Are there any memories that are especially important and vivid for you that you would like to share?

- Are there any events that are especially important and vivid for you that you would like to share?

- Are there any experiences that are especially important and vivid for you that you would like to share?

- What made you decide to leave life as a soldier or an officer?

- What emotions do you carry with you now as you are leaving life as a soldier or an officer?

(B) Questions to grasp relationships

- If you were to reflect for a while over your relationships, what persons are important for you?

- If you were to think for a while, are there any events that are important for you and your friends?

(C) Question to outline narrative identity

- If you were to reflect a while, do you find a situation or a pattern in a variety of situations that may describe you as a person or bring clarity to who you are?

- In what way does this situation or pattern over a variety of situations describe you?

(D) Questions to grasp existential concerns

- Can you reflect on a situation where you experienced significant life questions and maybe tell me that story?

- What is important for you in life?

- What gives you direction in life?

- What do you believe in? 